\title{
MODELING AND EXPERIMENTAL ANALYSIS OF PARABOLIC TROUGH SOLAR THERMAL STEAM GENERATION SYSTEM
}

\author{
Seid Endro, Haiter Lenin Allasi, Ayalew Yimam Ali \\ Department of Mechanical and Chemical Engineering, WOLLO University, \\ Kombolcha Institute of Technology, Kombolcha, Ethiopia
}

\begin{abstract}
The increasing trends in fossil fuel price with growing carbon dioxide emission have floating the globe to transfer towards renewable energy sources. This paper describes the design, modeling and analysis of a parabolic trough solar thermal steam generation for industries by renewable energy source. The study is concerted on substitute of boiler by solar energy system. The work is begun by investigating solar energy possible of preferred site and taking data from particular metrological substation of Dessie, energy require in $\mathrm{KWh}$ per day from the selected industrial unit and analyzing radiation energy potential using THERMO FLEX software. The most important objective of the solar field is to produce $\mathbf{1 5 7 6}$ KWh thermal energy production per day, which can be delivered to thermal load at sensible temperature. The industry uses furnace oil for production of steam, which consumes 750 liter oil in a year. Analysis of temperature supply in the absorber tube and flow modeling of heat exchanger has been carried out by ANSYS software. The result of this investigation is replacing furnace oil steam generation by solar thermal steam generation for a production industry and some useful conclusions are made.
\end{abstract}

Keywords- Solar energy, heat exchanger, modeling, parabolic trough

\section{INTRODUCTION}

Solar energy is one of the best renewable sources of energy. Dessie is originating in north-central part of Ethiopia in Amhara region at $11.13{ }^{\circ} \mathrm{C}$. North latitude and $39.6^{\circ}$ East longitude with an elevation of 2470 meter above sea level. Energy insufficiency has grown-up to be one of the most important problems in a number of regions of the country. The most important concentrator mirror usually consists of parabolic shaped glass faces that are coated with an extremely reflective metallic material. As a result, these mirrors present exceptional optical performance. The glass is heavy, expensive, requires a rigid sustaining structure Naeeni et al(2007).
The exchanging of solar energy into heat energy, an incident solar radiance is determined by concentrating solar collectors. For a lot of applications, it is attractive to deliver energy at temperatures superior than those potential with flatplate collectors. Energy release temperatures can be enlarged by declining the area from which heat losses take place. At presents oil is still rule world most important energy supply. Oil leads both coal and natural gas. Concentrated solar power systems make use of solar collector to pathway the sun and use its energy to manufacturing steam. Parabolic trough collector is the most common technology to concentrate the solar thermal energy onto absorbers and thermal energy transferred to a heat transfer fluid Naeeni et al. (2007).

The most important applications of PTC equipment for power generation can be seen in California, which has an installed capacity of $354 \mathrm{MW}$; and in Boulder City Nevada, where present is a solar thermal plant of $64 \mathrm{MW}$ capacities, owned by the ACCIONA Group Naeeni et al. (2007). The heat transfer from a receiver tube of a parabolic trough collector is $250 \mathrm{KW}$ solar steam production De Risi et al (2013). Iran is enchanting into enlightenment the effect of difference of collector angle of attack, wind speed and its sharing with reverence to elevation from the ground. Parabolic trough collectors consummate of generating temperature better than $150{ }^{\circ} \mathrm{C}$ were primarily developed for engineering process heating. More than a few parabolic trough developers sold their goods for industrial process of heat (IPH) systems in the 1970 s and 1980s, but in universal create three barriers to effectively selling their technologies Gang et al (2011).

The primary profit-making oil based parabolic trough collectors structure joint with conventional steam generating were built additional than 30 years ago Enibe (2003). In the United States parabolic trough collector equipment clarification for more than $1.3 \mathrm{GW}$ of steam generation capacity is present under creation or in function Padilla et al (2011). Parabolic trough collector systems are also human being built or formerly in process all over the world at whole electric power capacity of $800 \mathrm{MW}$ (excluding united states and Spain), with several new parabolic trough collectors steam generates being developed in India and other countries Bakos et al (2001). 


\section{International Journal of Engineering Applied Sciences and Technology, 2019 \\ Vol. 4, Issue 5, ISSN No. 2455-2143, Pages 19-29 \\ Published Online September 2019 in IJEAST (http://www.ijeast.com)}

Concentrated solar power systems are discussed to make use of solar energy as heat energy. It is planned to reduce the design cost and to improve the thermal efficiency of the parabolic troughs Silva et al (2013). The every year global solar-radiation received on a flat surface, for usual weather conditions, is $1725 \mathrm{kWh} / \mathrm{m}^{2}, 69 \%$ of this amount, (i.e. 1188 $\mathrm{kWh} / \mathrm{m}^{2}$ ) reaches the external as direct solar radiation and the rest, $31 \%$ (i.e. $537 \mathrm{kWh} / \mathrm{m}^{2}$ ), as diffuse radiation Hachicha et al.(2013), Padilla et al.(2011). There is no need for oil-water heat exchangers if water is directly evaporated and superheated in the solar field Kumar et al.(2009)., significant in a simpler plant design and lower investment costs. At last, the use of dematerialized water is economically unsuspecting: compared to oil, water is cheaper, non-toxic and nonflammable; compared to molten salt, water is less expensive and less corrosive Sandnes et al. (2002). Compared different solar concentrators in environment of their most significant characteristics, namely concentration, acceptance angle, sensitivity to mirror errors, size of reflector area and average number of reflections Hasanet al (1994).

Creation of steam using solar radiation is one of the greatest developing technologies at world point. The parabolic trough collector and the tracking structure are important for the concentration process. The receivers of parabolic trough have the mission to exchange the radiation that is expected onto them into heat and to carry the heat to the pipes. The solar radiation passes through the environment, some is absorbed and scattered by full of atmosphere substances such as ozone, oxygen, water, and dust. When solar rays pass through the environment perpendicularly when the sun is above our head, the solar flux is reduced by around 15 to $30 \%$, depending on time of year Nilsson et al (2007).

The earth rotates, causing the relation location of the sun to be different from sunrise to sunset, and assembly the altitude angle $(\alpha)$ vary from zero at sunrise to a maximum at solar noon, and again to zero at sunset. The angle of incidence is the angle between the solar rays and the surface ordinary.

$$
\begin{gathered}
\cos \theta_{i}=\sin \emptyset(\sin \delta \cos \beta+ \\
\cos \delta \cos \gamma \cos \omega \sin \beta)+ \\
\cos \emptyset(\cos \delta \cos \omega \cos \beta-\sin \delta \cos \gamma \sin \beta)+ \\
\cos \delta \sin \gamma \sin \omega \sin \beta
\end{gathered}
$$

Calculating $\theta$ is of great significance for solar system design and performance estimate since the quantity of collected solar energy is reduced by the cosine of this angle $\mathrm{Hu}$ et al. (1998). The outcome of the angle of incidence in dipping the regular irradiance on the opening area is incorporated in the cosine factor. There are other losses connected to the angle of incidence due to the difference of the mirror reflection and glass cover absorption with the difference of the angle of incidence. The influence of these losses on the collector performance is calculated by the incidence angle modifier $K(\theta)$. Here expressed in a polynomial function of $\theta$ (in degrees) as Nilsson et al.(1998), Rabin et al (1995).

$$
\begin{gathered}
K(\theta)=1-5.782 \times 10^{-3} \theta+1.485 \times \\
10^{-4} \theta^{2}-2.955 \times 10^{-6} \theta^{3}
\end{gathered}
$$

\section{MATERIALS AND METHODS}

\subsection{Parabolic trough collectors}

Big collector fields supply the thermal energy, which is used to produce steam for procedure heat. Parabolic trough collectors can give attention to sunlight with a concentration rate of around 40, based on the trough size. The focal line temperature can be as high as $350^{\circ} \mathrm{C}$ to $400^{\circ} \mathrm{C}$ Odeh et al (1998). The various sections of the trough collector are shown in Fig. 1.

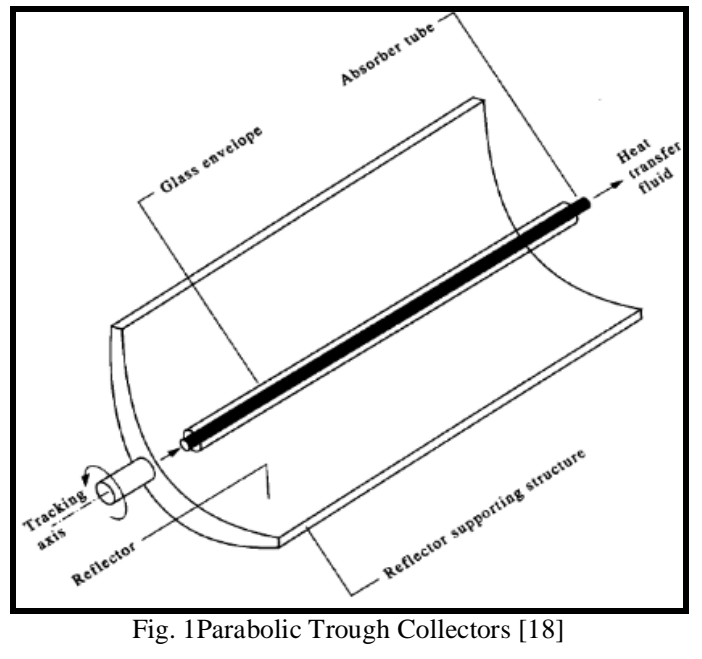

Parabolic trough collector tilted on the surface $20^{\circ}-30^{\circ}$ Zondag et al. (2002). on the horizontal surface. It is easy to formulate the beam radiation for tilted surface. For horizontal surface:

$$
\cos \theta_{z}=\frac{H_{b}}{H_{b_{t}}}
$$

For tilted surface:

$$
\cos \theta=\frac{H_{b t}}{H_{b n}}
$$

From the equations (3) and (4) the numerical factor $\mathrm{R}_{\mathrm{b}}$ can be calculated from the the radation of the tilted surface to the horizontal exterior by the following relations Sharaf et al.(1998). 


$$
R_{b}=\frac{H_{b t}}{H_{b}}=\frac{\cos \theta}{\cos \theta_{z}}
$$

$H_{T}=H_{b} \times R b$

$$
R_{b=}=\frac{\cos (\phi-\beta) \cdot \cos \delta \cdot \cos \omega+\sin (\phi-\beta) \sin \delta}{\cos \delta \cdot \cos \omega \cdot \cos \phi+\sin \phi \sin \delta}
$$

\subsection{Performance model of parabolic trough collector filed}

For solar collectors in general, the collector overall efficiency $\eta$ is defined as the ratio between the useful output $\mathrm{Qu}$ [W] delivered by the collector to the direct irradiance I $\left[\mathrm{W} / \mathrm{m}^{2}\right]$ incident on the collector aperture area Ac $\left[\mathrm{m}^{2}\right]$.

Collector efficiency

$\eta=\frac{m c_{p}\left(T_{c o}-T_{c i}\right)}{A_{c o l l} I_{T}}$

The single concentrator collector, the useful heat gain can be expressed as Mohamed et al. (2004).

$Q_{u}=F_{R} A_{a}\left[S-\frac{A_{r}}{A_{a}}\left(T_{i}-T_{a}\right)\right]$

Area of receiver $A_{r}=\prod D L$

Aperture area of the collector $A_{P}=(W-D) * L$

\subsection{Ansys}

ANSYS is the finite element code broadly use in computer aided engineering field and it help us to build computer model of structure, flow modeling, machine, components or system, apply working load and other design criteria, study physical reply such as stress level, temperature distribution, pressure distribution and velocity counters Zejli et al. (2004).

\section{Basic steep of ANSYS:}

* During pre processing the geometry of the problem is defined. The volume engaged by the fluid is separated into discrete cells (the mesh). The mesh may be uniform or non uniform and the physical modeling is defined. Boundary condition is defined.

* The simulation is started and equations are solved iteratively as steady and transit state.

* Finally a post procedure is used for the analysis and revelation of fluid flow.

ANSYS use numerical methods and algorism can be used to solve and analyze problems that involve the fluid flows and simulate the flow over a heat exchanger.

\subsection{Thermo flex software}

Thermo flex software used for design, simulation, cogeneration process, modeling of parabolic trough and it has all the mechanism wanted to model complete steam generation. It provides design point heat balance, physical apparatus size, and off-design performance. This software shows purpose of how much irradiance is incident on the receiver which in the end affects field efficiency and essential size to achieved desired heating.

* Thermo flex determines solar time from data using an equation of time. The relative sun collector positioning is used to decide azimuth and zenith angles coupled with the specific day and time.

* Thermo flex can establish pressure drop, cost estimation and heat transfer for receiver tubes shipping single phase thermal oils and single phase water.

\section{METHODOLOGY}

\subsection{Weather data collection}

During this investigation there are two categories of data collected, which serve as input for design and modeling of parabolic trough solar thermal steam generation system.

$>$ The first category of data is related to the metrological conditions at the site which are relevant to study of heat transfer characteristics of the system.

\begin{tabular}{|c|c|c|c|c|c|c|}
\hline Month & $\begin{array}{l}\text { Air } \\
\text { temper } \\
\text { ature }\end{array}$ & $\begin{array}{l}\text { Mont } \\
\text { hly } \\
\text { avera } \\
\text { ge } \\
\text { solar } \\
\text { radia } \\
\text { tion } \\
\text { - } \\
\text { horiz } \\
\text { ontal }\end{array}$ & $\begin{array}{l}\text { Win } \\
\text { d } \\
\text { spee } \\
d\end{array}$ & $\begin{array}{l}\text { Earth } \\
\text { temper } \\
\text { ature }\end{array}$ & $\begin{array}{l}\text { Relat } \\
\text { ive } \\
\text { humi } \\
\text { dity }\end{array}$ & $\begin{array}{l}\text { Atmos } \\
\text { pheric } \\
\text { pressu } \\
\text { re }\end{array}$ \\
\hline & ${ }^{0} \mathrm{C}$ & $\begin{array}{l}\text { KWh } \\
/ \mathrm{M}^{2} \\
{ }^{0} \mathrm{C}\end{array}$ & $\mathrm{m} / \mathrm{s}$ & ${ }^{0} \mathrm{C}$ & 86 & $\mathrm{KPa}$ \\
\hline January & 17.6 & 6.08 & 3.7 & 22.2 & 58.4 & 83.8 \\
\hline February & 19.2 & 6.41 & 3.8 & 24.6 & 52.2 & 83.7 \\
\hline March & 21.1 & 6.52 & 3.6 & 26.3 & 51.2 & 83.6 \\
\hline April & 21.9 & 6.54 & 3.2 & 26.6 & 52.9 & 83.6 \\
\hline May & 23.7 & 6.39 & 3 & 28.5 & 43.7 & 83.6 \\
\hline June & 22.8 & 5.8 & 3.5 & 25.8 & 55.4 & 83.5 \\
\hline July & 20.9 & 5.75 & 3.5 & 22.2 & 66.1 & 83.5 \\
\hline August & 20.9 & 5.9 & 3.2 & 21.9 & 66.4 & 83.5 \\
\hline September & 21.5 & 5.85 & 2.8 & 23.5 & 54.8 & 83.6 \\
\hline October & 20.6 & 6.19 & 2.6 & 23.9 & 45.1 & 83.7 \\
\hline November & 18.7 & 6.07 & 3 & 22.4 & 50.6 & 83.8 \\
\hline December & 17.5 & 5.85 & 3.2 & 21.6 & 57 & 83.8 \\
\hline
\end{tabular}

TABLE 1: DESSIE, ETHIOPIA - SOLAR ENERGY AND SURFACE

The second category of data is obtained from the engineering industry through discussion and mode questioner equipped to determine the actual working parameters and 


\section{International Journal of Engineering Applied Sciences and Technology, 2019 \\ Vol. 4, Issue 5, ISSN No. 2455-2143, Pages 19-29 \\ Published Online September 2019 in IJEAST (http://www.ijeast.com)}

daily water and power utilization in the facility is listed in Table 2.

\section{TABLE 2: DESSIE INDUSTRY ENERGY CONSUMPTION}

\begin{tabular}{ll}
\hline Operating temperature & 200 \\
Operating pressure & $10 \mathrm{bar}$ \\
Water consumption per day & 100,000 liter \\
Steam consumption kg steam /second & $12 \mathrm{~kg} / \mathrm{s}$ \\
Maximum Power consumption per day & $1576 \mathrm{KW}$ \\
\hline \hline
\end{tabular}

\subsection{Design and sizing of parabolic trough collector}

The designed parabolic trough collector is shown in Fig. 2. The simple parabolic equation in Cartesian coordinates is

$$
X^{2}=4 f y
$$

The height of the parabola in terms of the focal length and aperture diameter is $\left(\frac{a}{2}\right)^{2}=4 f h \sqrt{2}$

$$
h=\frac{a^{2}}{16 f}
$$

The rime angle $\psi_{\text {rim }}$ is given by $\operatorname{Tan} \frac{\psi_{\text {rim }}}{2}=\frac{a}{4 f}$

For a parabolic reflector, the radius $r=\frac{2 f}{1+\cos \psi}$

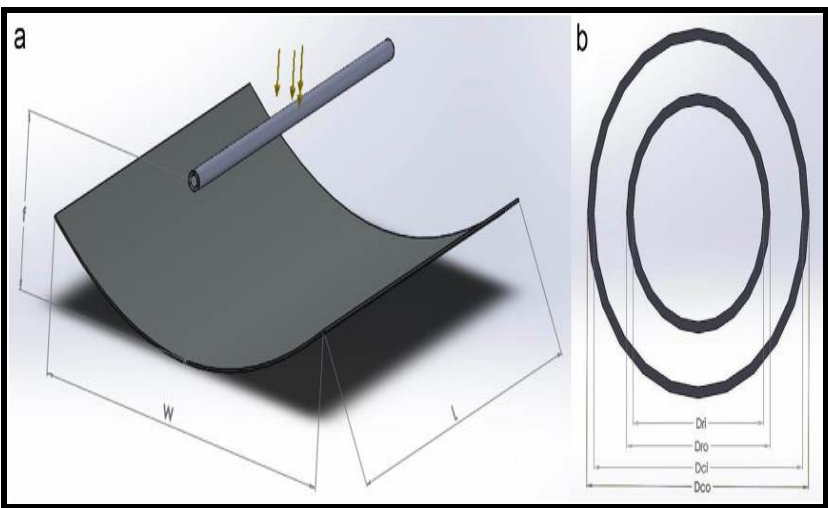

Fig. 2 Parabolic trough collector model design in solid work, (a) trough dimension, (b) evacuated tube dimension

\subsection{Modeling of absorber tube}

Modeling is performed the transit state temperature division of the absorber tube is determined by using ANSYS software. The investigation is carried out with the help of ANSYS software to simulate temperature distribution of absorber tube.

$$
\frac{d^{2} T}{d r^{2}}+\frac{1}{r} \frac{d T}{d r}=\rho c \frac{d T}{d t}
$$

Boundary conditions

$$
T(0, t)=T_{i} \& T(R, t)=T_{f}
$$

With boundary condition integrating the differential equation once respect to $r$ gives

$$
t_{i}=\frac{\rho C}{h \pi D_{o}^{2}}+\ln \frac{T_{i}-T_{f}}{T_{m p}-T_{f}}
$$

\subsection{Piping heat losses}

The HTF flowing inside the pipe at temperature $T$ (the mean HTF temperature across the solar field), the heat losses from the HTF to the surrounding is governed by

$Q_{p}=U_{p} A_{p}\left(T_{m}-T_{a}\right)$

$$
A_{o}=\pi D L_{P}\left(m^{2}\right)
$$

\subsection{Heat exchanger (Steam Generator)}

Heat exchanger can be designed for high pressure relative to environment and high pressure difference between the fluids. Heat received,

$$
\begin{gathered}
Q_{\text {in }=m}\left(H_{\text {in }}-H_{\text {out }}\right) \\
\text { Qin }=m c p(\text { Tout }- \text { Tin })
\end{gathered}
$$

The heat transfer rate across a heat exchanger is usually expressed in the form

$$
\dot{Q}=U A \Delta L M T D
$$

$\triangle \mathrm{LMTD}=$ Logarithmic-mean-temperature-difference Logarithmic-mean-temperature-difference for any heat exchanger can be calculated as follows:

$$
L M T D=\frac{\left(T_{\text {hot, in }}-T_{\text {cold }, \text { out }}\right)-\left(T_{\text {hot }, \text { out }}-T_{\text {cold , in }}\right)}{\ln \left(\frac{T_{\text {hot , in }}-T_{\text {cold }, \text { out }}}{T_{\text {hot }, \text { ou }} t-T_{\text {cold }, \text { in }}}\right)}
$$

\subsection{Flow modeling in Heat Exchangers using ANSYS CFX} From the continuity equation the quantity of fluid incoming in certain volume leaves that volume and momentum equation tells about the equilibrium of the momentum. The momentum equations are referred as Navierstrokes equation and most frequently used to explain fluid flow. The modeling of heat exchanger was based on transit state Navier -stroke equation.

$$
\begin{aligned}
& \frac{\partial \rho}{\partial t}+\frac{\partial(\rho u)}{\partial x}+\frac{\partial(\rho v)}{\partial y}+\frac{\partial(\rho w)}{\partial z}=0 \\
& \frac{\partial \rho}{\partial t}+\operatorname{Div}(\rho \vec{u})=0
\end{aligned}
$$

Also written as

$\mathrm{d} m=\sum \delta \min ^{-}-\sum \delta$ mout 


\section{International Journal of Engineering Applied Sciences and Technology, 2019 \\ Vol. 4, Issue 5, ISSN No. 2455-2143, Pages 19-29 \\ Published Online September 2019 in IJEAST (http://www.ijeast.com)}

This is summarized as: [mass accumulation over time $]=[$ sum of all inflows $]-[$ sum ofall outflows] Where $\delta$ represents area. Fluid flow in heat exchanger described by both continuity and Navier-equation. X-component of the incompressible Navier -stroke momentum equation $\rho\left(\frac{\partial u}{\partial t}+u \frac{\partial u}{\partial x}+v \frac{\partial u}{\partial y}+w \frac{\partial u}{\partial z}\right)=-\frac{\partial p}{\partial x}+\rho g_{x}+\mu\left(\frac{\partial^{2} u}{\partial x^{2}}+\frac{\partial^{2} u}{\partial y^{2}}+\frac{\partial^{2} u}{\partial z^{2}}\right)$

$\mathrm{Y}$ - component of the incompressible Navier-stroke momentum equation

$\rho\left(\frac{\partial v}{\partial t}+u \frac{\partial v}{\partial x}+v \frac{\partial v}{\partial y}+w \frac{\partial v}{\partial z}\right)=-\frac{\partial p}{\partial y}+\rho g_{y}+\mu\left(\frac{\partial^{2} v}{\partial x^{2}}+\frac{\partial^{2} v}{\partial y^{2}}+\frac{\partial^{2} v}{\partial z^{2}}\right)$

Z- component of the incompressible Navier -stroke momentum equation

$\rho\left(\frac{\partial w}{\partial t}+u \frac{\partial w}{\partial x}+v \frac{\partial w}{\partial y}+w \frac{\partial w}{\partial z}\right)=-\frac{\partial p}{\partial z}+\rho g_{z}+\mu\left(\frac{\partial^{2} w}{\partial x^{2}}+\frac{\partial^{2} w}{\partial y^{2}}+\frac{\partial^{2} w}{\partial z^{2}}\right)$

The diameter of the tube was measured $15 \mathrm{~cm}$ and the length was measured $250 \mathrm{~cm}$. The flow is unspecified to be steady and turbulent and physical properties of water are constant. ANSYS software is used to model the heat exchanger in order to get the temperature, pressure and velocity distribution.

The diameter of the tube was measured $15 \mathrm{~cm}$ and the length was measured $250 \mathrm{~cm}$. The flow is unspecified to be steady and turbulent and physical properties of water are constant. ANSYS software is used to model the heat exchanger in order to get the temperature, pressure and velocity distribution.

\section{DESIGN CALCULATIONS}

\subsection{Calculation of Sunset Hour Angles}

Monthly values of $\mathrm{n}, \delta$ and $\omega_{s}$ Are listed in Table 3after the calculations

Calculation of the sunset hour angle $\left(\omega_{s}\right)$ is given by the expression $\cos \omega_{s}=-\tan \delta \tan \varphi$

At $\mathrm{n}=17$ the declination angle (January $17^{\text {th }}$ )

$$
\delta=23.45 \sin \left(\frac{360(284+N)}{365}\right)
$$

TABLE III: MONTHLY VALUES OF $\mathrm{N}, \quad$ AND $\omega_{s}$

\begin{tabular}{llll}
\hline \hline Month & $\boldsymbol{n}$ & $\boldsymbol{\delta}$ & $\boldsymbol{\omega}_{S}$ \\
\hline January & 17 & -20.92 & 85.7 \\
February & 47 & -13 & 87.4 \\
March & 75 & -2.4 & 89.5 \\
April & 105 & 9.4 & 91.9 \\
May & 135 & 18.8 & 93.9 \\
June & 162 & 23.1 & 94.9 \\
July & 198 & 21.1 & 94.5 \\
August & 228 & 13.5 & 92.8 \\
September & 258 & 2.2 & 90.4 \\
October & 288 & -9.6 & 88 \\
November & 318 & -18.9 & 86 \\
December & 344 & -23 & 85 \\
\hline \hline
\end{tabular}

4.2. Calculation monthly average extraterrestrial solar radiation

$\overline{H O}=\frac{24 \times 3600 x 1367}{\pi}\left(1+0.039 \cos \frac{360 n}{365}\right)\left[\cos \varnothing \cos \delta \sin \omega s+\left(\frac{\pi \omega s}{180}\right) \sin \delta \sin \varnothing\right]$

The calculated value of monthly average of extraterrestrial solar radiation and monthly average horizontal radiation is listed in Table 4.

TABLE IV: VALUE OF MONTHLY AVERAGE OF EXTRATERRESTRIAL SOLAR RADIATION AND MONTHLY AVERAGE HORIZONTAL RADIATION

\begin{tabular}{|c|c|c|c|c|c|c|c|c|c|c|c|c|}
\hline & $\overleftrightarrow{\Xi}$ & $\frac{7}{8}$ & 疋 & $\frac{8}{0}$ & $\underset{2}{3}$ & 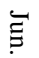 & $\Xi$ & $\underset{00}{D}$ & $\frac{\pi}{8}$ & 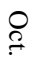 & 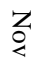 & 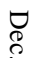 \\
\hline$\overline{\mathrm{Ho}}$ & $\begin{array}{c}31 \\
.6\end{array}$ & $\begin{array}{c}38 \\
.6\end{array}$ & 38 & $\begin{array}{l}37 \\
.3\end{array}$ & $\begin{array}{c}36 \\
.6\end{array}$ & 36 & $\begin{array}{c}36 \\
.2\end{array}$ & $\begin{array}{l}37 \\
.7\end{array}$ & $\begin{array}{l}36 \\
.7\end{array}$ & 35 & $\begin{array}{c}35 \\
.2\end{array}$ & 30 \\
\hline$\overline{\overline{H T}}$ & $\begin{array}{l}6 . \\
08\end{array}$ & $\begin{array}{l}6 . \\
41\end{array}$ & $\begin{array}{l}6 . \\
52\end{array}$ & $\begin{array}{l}6 . \\
54\end{array}$ & $\begin{array}{l}6 . \\
39\end{array}$ & $\begin{array}{l}5 . \\
77\end{array}$ & $\begin{array}{l}5 . \\
55\end{array}$ & $\begin{array}{l}5 . \\
56\end{array}$ & $\begin{array}{l}5 . \\
85\end{array}$ & $\begin{array}{l}6 . \\
19\end{array}$ & $\begin{array}{l}6 . \\
07\end{array}$ & $\begin{array}{l}5 . \\
85\end{array}$ \\
\hline
\end{tabular}

$\mathrm{H} \overline{\mathrm{T}}$ is taken from table 3.1

\subsection{Monthly average absorbed radiation}

We take concentrated parabolic collector consisting of steel reflector covered with silver foil of reflectivity 0.85 , Transmissivity 0.95 and absorber tube is copper material coated with back copper of absopitivity 0.96 Hachicha et.al (2013). From equation (7) the geometric factor (Rb) is 1.2. The calculated Mean value of $\bar{S}$ and $\overline{H T}$ is listed in Table 5 and the variation of absorbance with angle of incidence from ASME is listed in Table 6. The specification details are in Table 7.

$$
\begin{aligned}
& \overline{H T}=H_{B} \times R b \\
& \bar{S}=(\tau \alpha) \overline{H T}
\end{aligned}
$$

TABLE V: MEAN VALUE OF $\bar{S}$ AND $\overline{H T}$

\begin{tabular}{lcc}
\hline \hline Month & $\overline{H T}\left(K W h / m^{2} \cdot d\right)$ & $\bar{S}\left(K W h / m^{2} \cdot d\right)$ \\
\hline January & 6.08 & 6.41 \\
February & 7.29 & 7.69 \\
March & 6.08 & 6.41 \\
April & 7.29 & 7.69 \\
May & 6.08 & 6.41 \\
June & 7.29 & 7.69 \\
\hline
\end{tabular}


International Journal of Engineering Applied Sciences and Technology, 2019

Vol. 4, Issue 5, ISSN No. 2455-2143, Pages 19-29

Published Online September 2019 in IJEAST (http://www.ijeast.com)

\begin{tabular}{lll}
\hline July & 6.08 & 6.41 \\
August & 7.29 & 7.69 \\
September & 6.08 & 6.41 \\
October & 7.29 & 7.69 \\
November & 6.08 & 6.41 \\
December & 7.29 & 7.69 \\
\hline \hline
\end{tabular}

TABLE VI: VARIATION OF ABSORBANCE WITH ANGLE OF INCIDENCE FROM ASME

\begin{tabular}{cc}
\hline \hline Angle of incidence( & Absorbance $(\alpha)$ \\
\hline $0-30$ & 0.96 \\
$30-40$ & 0.95 \\
$40-50$ & 0.93 \\
$50-60$ & 0.91 \\
$60-70$ & 0.88 \\
$70-80$ & 0.81 \\
$80-90$ & 0.66 \\
\hline \hline
\end{tabular}

TABLE VII: PARABOLIC TROUGH COLLECTOR SPECIFICATION [8, 9]

\begin{tabular}{|c|c|c|c|}
\hline Length & $22 \mathrm{~m}$ & $\begin{array}{l}\begin{array}{l}\text { Emissivity } \\
\text { cover }\end{array} \\
\text { of }\end{array}$ & 0.88 \\
\hline Focal length & $80 \mathrm{~cm}$ & $\begin{array}{l}\text { Transmissivity of } \\
\text { cover } \tau\end{array}$ & 0.95 \\
\hline Aperture & $3 \mathrm{~m}$ & $\begin{array}{l}\text { Reflectivity of } \\
\text { mirror } \rho\end{array}$ & 0.85 \\
\hline Width & $3.5 \mathrm{~m}$ & $\begin{array}{l}\text { Absorptive of the } \\
\text { receiver } \alpha\end{array}$ & 0.96 \\
\hline $\begin{array}{l}\text { Outer } \\
\text { diameter of } \\
\text { receiver }\end{array}$ & $65 \mathrm{~mm}$ & $\begin{array}{l}\text { Emissivity of } \\
\text { receiver }\end{array}$ & 0.15 \\
\hline $\begin{array}{l}\text { Outer } \\
\text { diameter of } \\
\text { cover }\end{array}$ & $120 \mathrm{~mm}$ & Rim angle & 90 \\
\hline
\end{tabular}

\subsection{Over all heat loss analysis}

Overall heat loss can be calculated by the following relations,

$$
\begin{gathered}
U_{l}=\left[\frac{A_{r}}{\left(h_{w}+h_{r-c-a}\right) A_{c}}+\frac{1}{h_{r, r-c}}\right]^{-1} \\
h_{r-c-a}=\varepsilon_{c} \sigma\left(T_{c}+T_{a}\right)\left(T_{c}^{2}+T_{a}^{2}\right) \\
\left.h_{r, r-c}=\frac{\sigma\left(T_{c}+T_{r}, a v\right.}{\frac{1}{\varepsilon_{r}}+\frac{A_{r}}{A_{c}}\left(\frac{1}{\varepsilon_{c}}-1\right)} T_{c}^{2}+T_{r, a v}^{2}\right)
\end{gathered}
$$

\subsection{Modeling of pipe}

The dimensions of the insulated pipe are listed in Table 8.

TABLE VIII: DIMENSION OF INSULATED PIPE

\begin{tabular}{cccc}
\hline \hline No & Descriptions & Unit & Value \\
\hline 1 & Inner diameter of the pipe $\left(\mathrm{D}_{1}\right)$ & $\mathrm{Mm}$ & 80 \\
2 & Outer diameter of the pipe $\left(\mathrm{D}_{2}\right)$ & $\mathrm{Mm}$ & 90 \\
3 & Diameter of insulated material $\left(\mathrm{D}_{3}\right)$ & $\mathrm{Mm}$ & 200 \\
4 & Length of the pipe & $\mathrm{Mm}$ & 15000 \\
5 & Thermal conductivity of the pipe & W/m.K & 67 \\
6 & Thermal conductivity of insulated & W/m.K & 2.5 \\
& material & \\
\hline \hline
\end{tabular}

The basic model for calculating heat loss of pipe UP [W/m2.K] Zejli et al. (2012).

$$
\begin{aligned}
& U_{p}= \frac{1}{h_{\text {out }}}+\frac{D_{3} \ln \left(\frac{D_{3}}{D_{2}}\right)}{2 \times K_{i}}+\frac{D_{3}}{D_{1} h_{\text {in }}}+\frac{D_{3} \ln \left(\frac{D_{2}}{D_{1}}\right)}{2 \times K_{p}} \\
& N u=\frac{\left(\frac{f}{8}\right)(\operatorname{Re}-1000) p r}{1+12.7\left(\frac{f}{8}\right) 0.5\left(p r^{0.67}-1\right)}
\end{aligned}
$$

The convection heat loss coefficient between the cover and

4.5. Modeling of parabolic trough solar thermal steam generation

$$
\begin{gathered}
F^{\prime}=\frac{U_{O}}{U_{L}} \\
F_{R}=\frac{m C_{p}}{A_{c} U_{L}}\left[1-\exp \left(\frac{A_{c} U_{L} F^{\prime}}{m C_{p}}\right)\right]
\end{gathered}
$$

(1)

$$
h_{w}=\frac{N u K}{D}
$$




\section{International Journal of Engineering Applied Sciences and Technology, 2019 \\ Vol. 4, Issue 5, ISSN No. 2455-2143, Pages 19-29 \\ Published Online September 2019 in IJEAST (http://www.ijeast.com)}

\section{RESULTS AND DISCUSSIONS}

\subsection{Effect of declination angle}

Fig. 3 shows the effect of variation of declination angle with mean day of the month.

The instantaneous declination angles are calculated during day time at $1 \mathrm{hr}$ of intervals from sunset to sunrise. The declination angle varies from a maximum value of $+24.45^{\circ}$ to a minimum value of $-22.45^{\circ}$ as show in Fig. 3 .

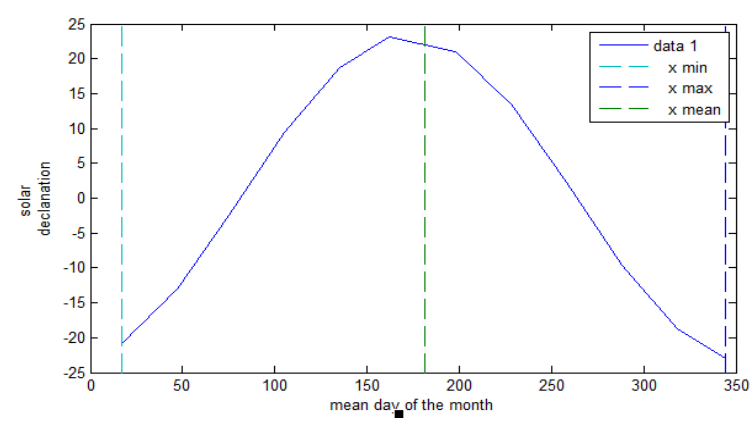

Fig. 3 Variation of declination angle with mean day of the month

The hour angle corresponding to sunrise or sunset $\left(\omega_{\mathrm{st}}\right)$ on an inclined surface facing due south $\left(\gamma=0^{\circ}\right)$ Pigozzo et al. (2014). The hour angle $\omega$ is negative before solar noon and positive after solar noon. The sun shine angle varies from a maximum value of +95 to a minimum value of 85 as show in Fig. 4.

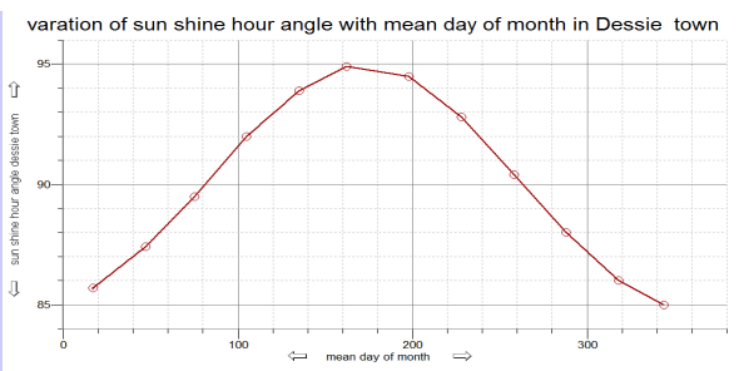

Fig. 4 Sun shine hour angle verses mean day of month

Solar radiation parameters are predictable from above Eqs. The parameters are predictable at noon time of $21^{\text {st }}$ of each month of 2016. Therefore, immediate hour angle at solar noon $(\omega)$ is zero. The collector slope angle $(\xi)$ and surface azimuth angle $(\gamma)$ are measured as $30^{\circ}$ and $0^{\circ}$ respectively [23]. Results showed that the straight radiation is higher in Fuqiang et al. (2017), intensity to the global radiation throughout the summer, post monsoonal and winter months due to clear sky conditions and variations in altitude angle. The average value of global radiation for 1 st 6 month is 984.5 $\mathrm{W} / \mathrm{m}^{2}$ and 2 nd 6 month is $985.5 \mathrm{~W} / \mathrm{m}^{2}$ as shown in Fig. 5.

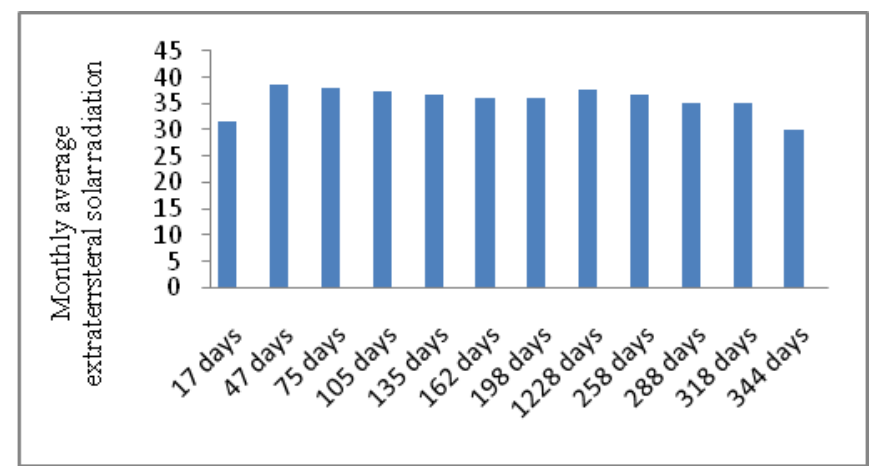

Fig. 5 Variation of Extraterrestrial solar radiation with mean day of the month

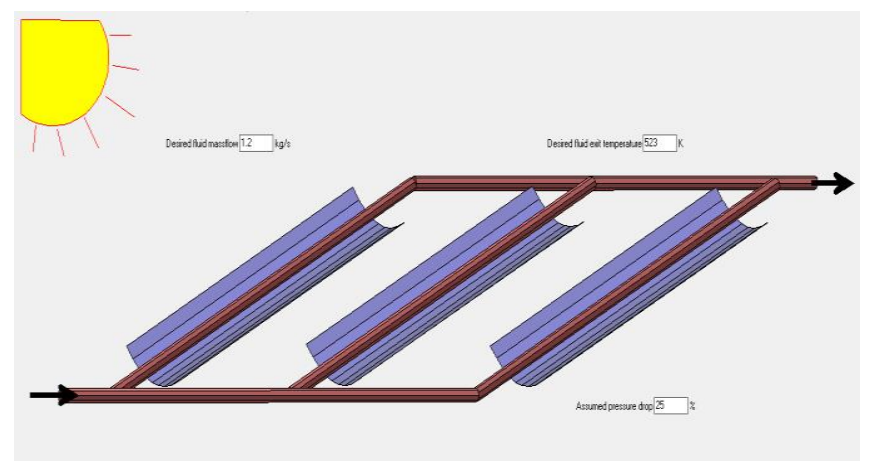

Fig. 6 Modeling of parabolic trough collector with Thermo flex software

Fig. 6 shows the modeling of parabolic trough collector by particular the collector absorber tube diameter, inlet and outlet temperature. The parameters measured for modeling of parabolic trough collector are length of the collector, diameter of the collector and flow rates. The parabolic trough solar collector is transit -state model and based on the energy balance and heat transfer mechanism within parabolic trough solar collector's receiver tube. It could determine the small part of the incident solar energy improved in the fluid circulating through the pipe receiver, the pressure drop of the fluid greater than the receiver, thermal loss from the collector, and the temperature of the collector and direct normal solar irradiation, incidence angle and wind speed. The primary purpose of the model is predicting solar collector efficiency that is thermal energy output of parabolic trough solar collector. Parabolic trough solar collector is able of using only beam insulation. Any diffuse insulation is lost to the concentrator.

\subsection{Model analysis of absorber tube and analysis}




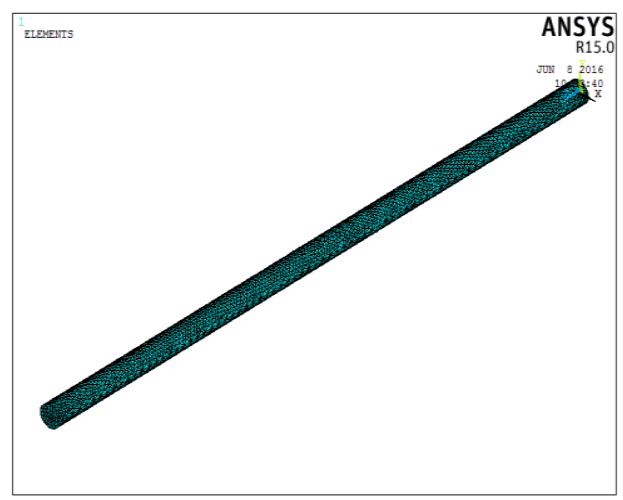

Fig. 7 Meshing of absorber tube

Here the ANSYS model of absorber tube is divided into several numbers of nodes and elements. Meshing is required to get the solution at different location of absorber tube. This mesh contains mixed cells having a faces at the boundary. The geometry is divided into several parts for using automatic methods available in the ANSYS meshing client as shown in Fig. 7. In pre processing stage the fluid properties and boundary conditions are given in SI unites and set the boundary condition of inlet and outlet temperature at given length and tube diameter of the absorber tube. Fig. 8 shows the absorber tube temperature distributions in using the ANSYS.

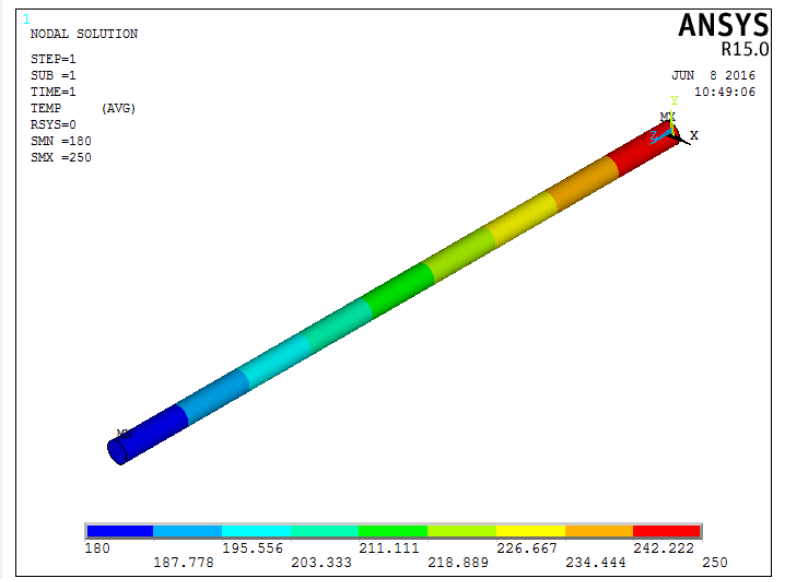

Fig. 8 Absorber tube temperature distributions in ANSYS

Fig. 9 shows the temperature distribution of water in a cross section. It shows that the fluid is warmer in the top part, because the absorber is warmer in the respective part. The red color shows the warmer part of the fluid and the temperature difference between the maximum and minimum is $70{ }^{\circ} \mathrm{C}$ which show the temperature distribution is no uniform. The maximum and minimum temperature in the absorber tube is $180{ }^{\circ} \mathrm{C}$ and $250{ }^{\circ} \mathrm{C}$ respectively and the mean temperature of the tube is $215^{\circ} \mathrm{C}$. Fig. 10 shows the Modeling of pipe using the Thermo flex software

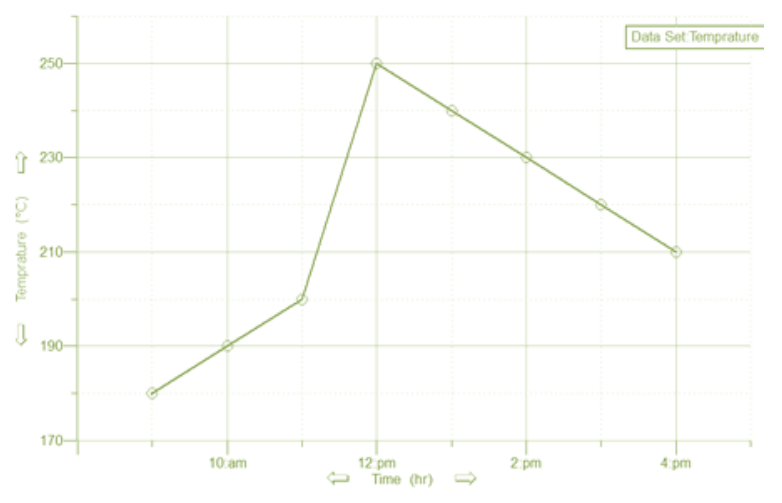

Fig. 9 Temperature verses time of absorber tube

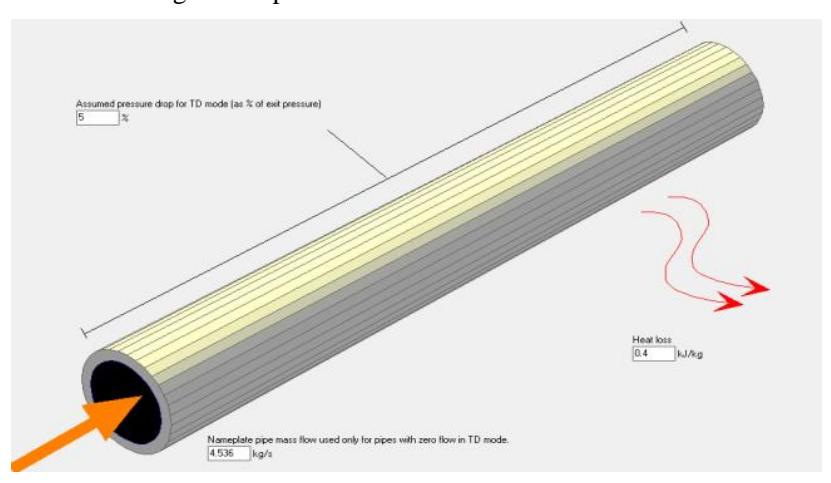

Fig. 10 Modeling of pipe in Thermo flex software

\subsection{Analysis of heat exchanger}

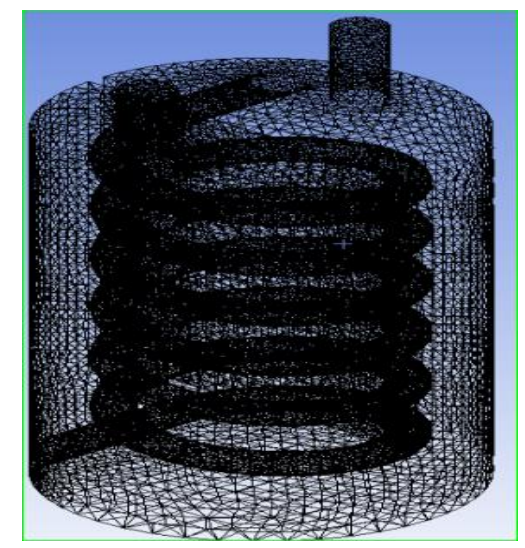

Fig. 11 Flow modeling mesh heat exchanger

Fig.11 shows the mesh diagram of the heat exchanger. In Fig. 12 the entire geometry is divided in to three fluid domains fluid inlet, fluid wall and fluid outlet. The heat exchanger discretized in to solid and fluid domains in order to in order to have better control the number of nodes Chandra et al. (2017). The fluid mesh is made finer then solid mesh for simulating heat transfer process. Mesh contains mixed cells and having different faces at the boundaries. 


\section{International Journal of Engineering Applied Sciences and Technology, 2019 \\ Vol. 4, Issue 5, ISSN No. 2455-2143, Pages 19-29 \\ Published Online September 2019 in IJEAST (http://www.ijeast.com)}

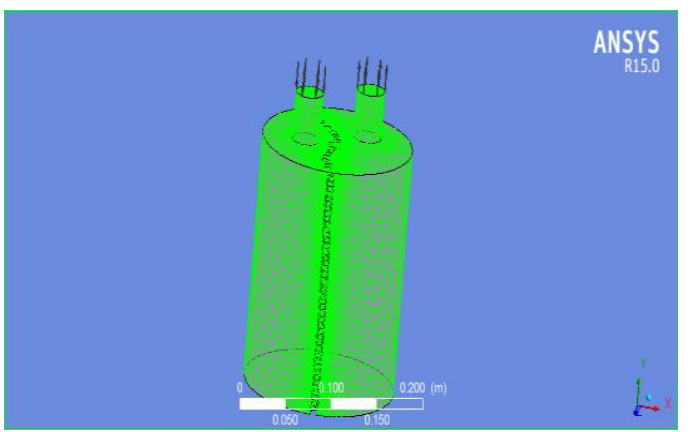

Fig. 12 Inlet and outlet flow of heat exchanger

Fig. 13shows the inlet and out let flow in heat exchanger at the top of the tube. This figure shows the modeling of inlet and outlet temperature and pressures are specified.

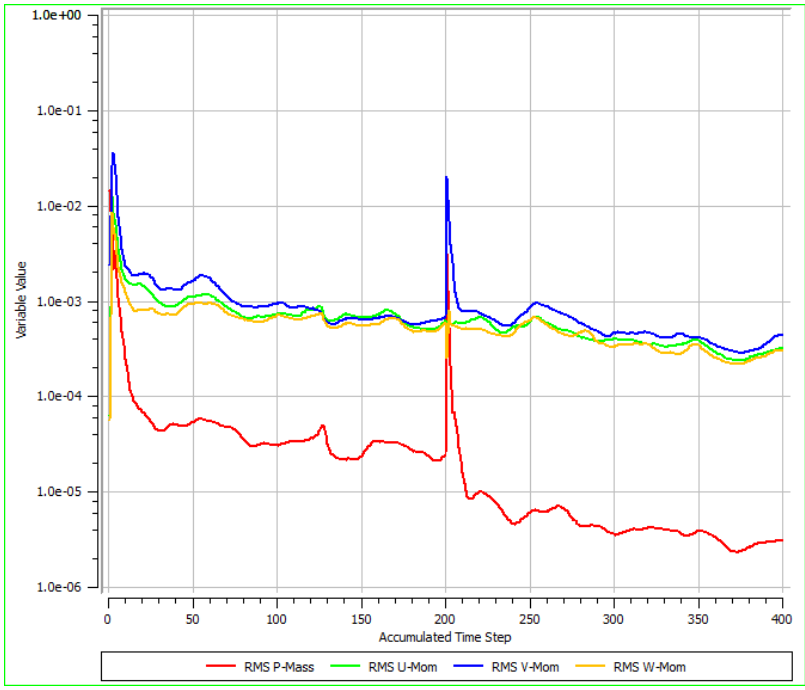

Fig. 13 Pressure and Velocity verses Time Diagram

RMS-P = Reynolds Momentum stress - pressure analysis RMS-U = Reynolds Momentum stress - velocity at X' RMS-V $=$ Reynolds Momentum stress - velocity at ' $Y$ ' RMS-W = Reynolds Momentum stress -velocity at ' $\mathrm{Z}$ '

The variable value in the ' $\mathrm{Y}$ value represents the mass and the momentum. Fig. 14 shows the pressure, velocity $\mathrm{U}$ at ' $\mathrm{X}$ ', velocity $\mathrm{V}$ at' $\mathrm{Y}$ ' and velocity $\mathrm{W}$ at ' $\mathrm{Z}$ '. Pressure and velocity are maximum at midpoint of the throat. Both pressure and velocity increase with increase of mass and momentum up to 5 accumulation time. The result is calculated by integration of continuity and Navier equation in such a way that the pressure appears in the continuity equation.

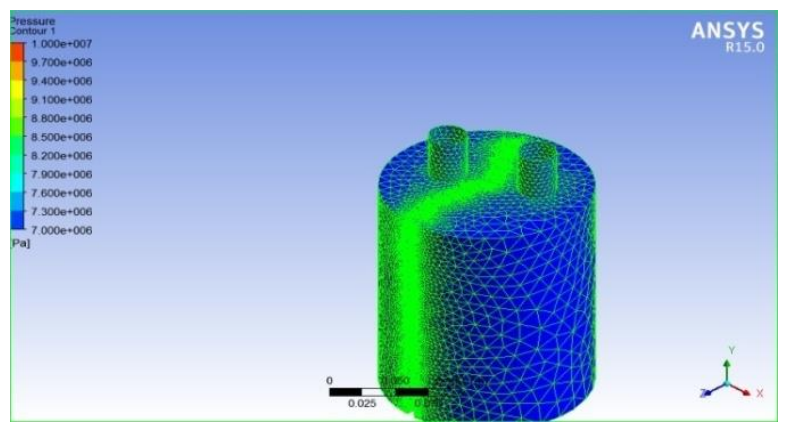

Fig. 14 Pressure filed flow model of Heat Exchanger

Fig. 15 shows the pressure distribution across the heat exchanger. The minimum and maximum pressures are 7 bar and 10 bar respectively. Pressure will increase from inlet to outlet. The pressure distribution of the flow medium is counter flow.

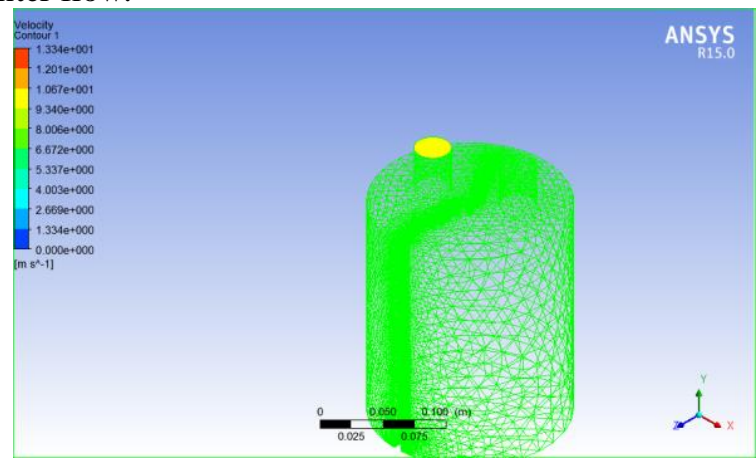

Fig. 15 Velocity flow model of inlet and outlet Heat Exchanger

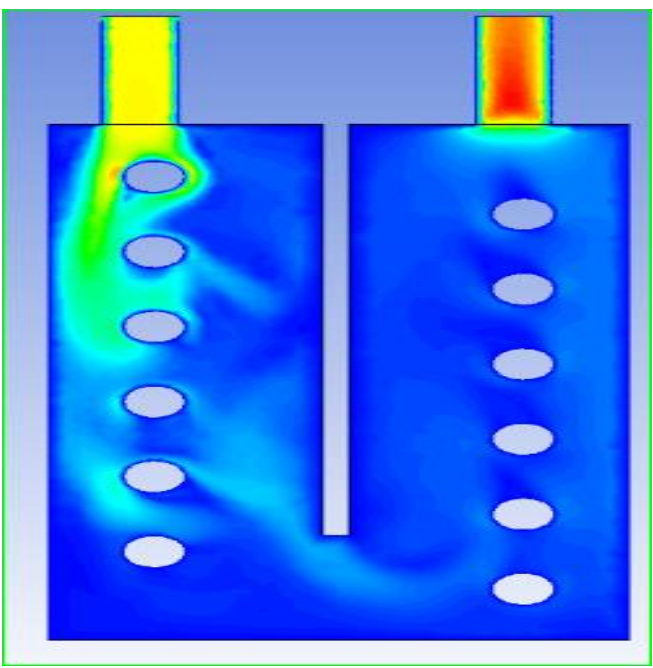

Fig. 16 Velocity Profile of Heat Exchanger

The Velocity of water profile is examined to understand the flow distribution across the cross section different positions of the heat exchanger. In the above Fig. 16 is the velocity profile of the heat exchanger at different positions. The four variables or unknowns (pressure and three velocities) are determined by continuity and momentum equation. 


\section{International Journal of Engineering Applied Sciences and Technology, 2019 \\ Vol. 4, Issue 5, ISSN No. 2455-2143, Pages 19-29 \\ Published Online September 2019 in IJEAST (http://www.ijeast.com)}

\section{CONCLUSIONS}

Parabolic trough solar thermal steam generation use water as a heat transfer fluid (HTF). Economic assessment of parabolic trough steam generator and conventional steam generator has been done for Dessie industries. It uses furnace oil for steam generation, consumes 270,000 liter sand pays $4,320,000$ birr in a year. During cloud day conventional backup steam generation system is used for few days in a year. In the industry itself, the use of an alternative energy produce significant saving in energy costs will increase the competitiveness of the companies, with reduction of costs. The goal of the system was to provide $1576 \mathrm{KW}$ thermal energy.

The output from parabolic trough collector is 344.56 $\mathrm{KW}$ per collector and it is depend on the available solar flux, which varies due to both the sun position and local weather conditions. Alternative fuel is used in the industries, oil cannot be completely avoided in the boiler. But to a certain extent quantity of oil are used can be reduced. This thesis goal to study the usage of alternative fuels in boiler and its work benefit in a soft drink industry. This study is very important for industries for reducing the overall production cost. Temperature of the hot water in heat exchanger at inlet was $523 \mathrm{~K}$ and in outlet it became $473 \mathrm{~K}$. In case of cold water inlet temperature was $293 \mathrm{~K}$ and the outlet became $333 \mathrm{k}$.

Generally, the operating cost for solar parabolic trough is very low as compared to furnace oil fired boiler but initial investment cost of parabolic trough steam generator high. The result show solar parabolic trough is more economical for steam generation than furnace oil fired boiler.

\section{Nomenclature}

Where: $\mathrm{Hbn}=$ Beam radiation at normal incidence $H b=$ Beam radiation on horizontal surface $H b t=$ Beam radiation on tilted surface

Where $\mathrm{L}$ is length of collector and $\mathrm{D}$ is diameter of receiver Where $\varnothing=$ latitude of the location $\left(, \varnothing=11.13^{\circ}\right.$ for Dessie) $\delta=$ solar declination

$\mathrm{n}=$ mean day of the month

$\mathrm{Ar}=$ area of receiver

Ac $=$ Area of cover

$h r-c-a=$ the radiation heat transfer coefficient between the glass cover and surrounding

$h r, r-c=$ the radiation heat transfer coefficient between the receiver and cover

$h w=$ wind heat transfer coefficient

$c$ is the emittance of the cove

$\sigma$ is Sefan Boltzmann constant.

The radiation heat transfer between the receiver and the cover as: $\quad \sigma=5.67 \times 10-8 \mathrm{~W} / \mathrm{m} 2 \mathrm{~K}$

Where $r$ the emittance of the receiver and the subscript av is refers to average.

$\mathrm{Nu}$ is the nusselt number and $\mathrm{K}$ is the thermal conductivity of the air.

\section{REFERENCES}

[1] Naeeni, N., and M. Yaghoubi. "Analysis of wind flow around a parabolic collector (1) fluid flow." Renewable Energy 32.11 (2007): 1898-1916.

[2] De Risi, A., M. Milanese, and D. Laforgia. "Modelling and optimization of transparent parabolic trough collector based on gas-phase nanofluids." Renewable Energy 58 (2013): 134-139.

[3] Gang, Pei, Li Jing, and Ji Jie. "Design and analysis of a novel low-temperature solar thermal electric system with two-stage collectors and heat storage units." Renewable Energy 36.9 (2011): 2324-2333.

[4] Enibe, S. O. "Thermal analysis of a natural circulation solar air heater with phase change material energy storage." Renewable Energy 28.14 (2003): 2269-2299.

[5] Padilla, Ricardo Vasquez, et al. "Heat transfer analysis of parabolic trough solar receiver." Applied Energy 88.12 (2011): 5097-5110.

[6] Bakos, G. C., et al. "Design, optimisation and conversion-efficiency determination of a line-focus parabolic-trough solar-collector (PTC)." Applied energy 68.1 (2001): 43-50.

[7] Silva, R., M. Pérez, and A. Fernández-Garcia. "Modeling and co-simulation of a parabolic trough solar plant for industrial process heat." Applied energy 106 (2013): 287-300.

[8] Hachicha, A. A., et al. "Numerical simulation of wind flow around a parabolic trough solar collector." Applied energy 107 (2013): 426-437.

[9] Padilla, R., and Gokmen Demirkaya. "G Goswami Y, Stefanakos E, Rahman M." Heat transfer analysis of parabolic trough solar receiver. Applied eneenergy 88 (2011): 5097-110.

[10] Kumar, K. Ravi, and K. S. Reddy. "Thermal analysis of solar parabolic trough with porous disc receiver." Applied Energy 86.9 (2009): 1804-1812.

[11] Sandnes, BjØrnar, and John Rekstad. "A photovoltaic/thermal (PV/T) collector with a polymer absorber plate. Experimental study and analytical model." Solar Energy 72.1 (2002): 63-73.

[12] Hasan, Afif. "Phase change material energy storage system employing palmitic acid." Solar energy 52.2 (1994): 143-154.

[13] Nilsson, Johan, Håkan Håkansson, and Björn Karlsson. "Electrical and thermal characterization of a PV-CPC hybrid." Solar Energy 81.7 (2007): 917-928.

[14] Hu, Eric J. "A study of thermal decomposition of methanol in solar powered adsorption refrigeration systems." Solar Energy 62.5 (1998): 325-329.

[15] Rabin, Y., et al. "Integrated solar collector storage system based on a salt-hydrate phase-change material." Solar Energy 55.6 (1995): 435-444.

[16] Odeh, S. D., G. L. Morrison, and M. Behnia. "Modelling of parabolic trough direct steam generation 


\section{International Journal of Engineering Applied Sciences and Technology, 2019 \\ Vol. 4, Issue 5, ISSN No. 2455-2143, Pages 19-29 \\ Published Online September 2019 in IJEAST (http://www.ijeast.com)}

solar collectors." Solar energy 62.6 (1998): 395-406.

[17] Zondag, Herman A., et al. "The thermal and electrical yield of a PV-thermal collector." Solar energy 72.2 (2002): 113-128.

[18] Sharaf, Mohamed A., A. S. Nafey, and Lourdes García-Rodríguez. "Exergy and thermo-economic analyses of a combined solar organic cycle with multi effect distillation (MED) desalination process." Desalination 272.1-3 (2011): 135-147.

[19] Mohamed, Essam Sh, and G. Papadakis. "Design, simulation and economic analysis of a stand-alone reverse osmosis desalination unit powered by wind turbines and photovoltaics." Desalination 164.1 (2004): 87-97.

[20] Zejli, D., et al. "Economic analysis of wind-powered desalination in the south of Morocco." Desalination 165 (2004): 219-230.

[21] Hassan, H. Z., A. A. Mohamad, and H. A. Al-Ansary. "Development of a continuously operating solar-driven adsorption cooling system: Thermodynamic analysis and parametric study." Applied Thermal Engineering 48 (2012): 332-341.

[22] Pigozzo Filho, Victor C., et al. "Experimental and numerical analysis of thermal losses of a parabolic trough solar collector." Energy Procedia 57 (2014): 381-390.

[23] Fuqiang, Wang, et al. "Progress in concentrated solar power technology with parabolic trough collector system: a comprehensive review." Renewable and Sustainable Energy Reviews 79 (2017): 1314-1328.

[24] Chandra, Yogender Pal, et al. "Numerical optimization and convective thermal loss analysis of improved solar parabolic trough collector receiver system with one sided thermal insulation." Solar Energy 148 (2017): 36-48. 